\title{
70 Years of coercion in German psychiatric Institutions, experienced and witnessed Dorothea Buck
}

from WPA Thematic Conference. Coercive Treatment in Psychiatry: A Comprehensive Review

Dresden, Germany. 6-8 June 2007

Published: 19 December 2007

BMC Psychiatry 2007, 7(SuppI I):S6 doi:10.1 186/I47I-244X-7-SI-S6

This abstract is available from: http://www.biomedcentral.com/I47I-244X/7/SI/S6

(c) 2007 Buck; licensee BioMed Central Ltd.

Dorothea Buck was born in Germany in 1917 and can therefore be called a contemporary witness. She had five stays in psychiatric hospitals in the period from 1936 to 1959 and was subjected to various forms of coercion, such as forced sterilization, cold wet sheet packs and forced injections and was never granted a single talk about the origin or meaning of her psychotic episodes. Facing the historical development of psychiatry and its effects on today's mental health system, she challenges biological psychiatry, which rejects communication with patients, and demands a paradigm shift toward a psychosocial system based on the wealth of patients' experiences that provides alternatives to psychiatry, such as the therapeutic principles of "Soteria" and Yrjö Alanen's "need-adapted treatment." 